\title{
MaY 241965
}

\section{THE MINERAL INDUSTRIES EXPERIMENT STATION \\ College of Mineral Industries \\ THE PENNSYLVANIA STATE UNIVERSITY}

Final Research Report

Contract No. U.S.A.E.C. At (30-1)-2000

AN INVESTIGATION OF THE

MINERALOGY, PETROGRAPHY, AND PAIEOBOTANY

OF URANIUM-BEARING LIGNITES
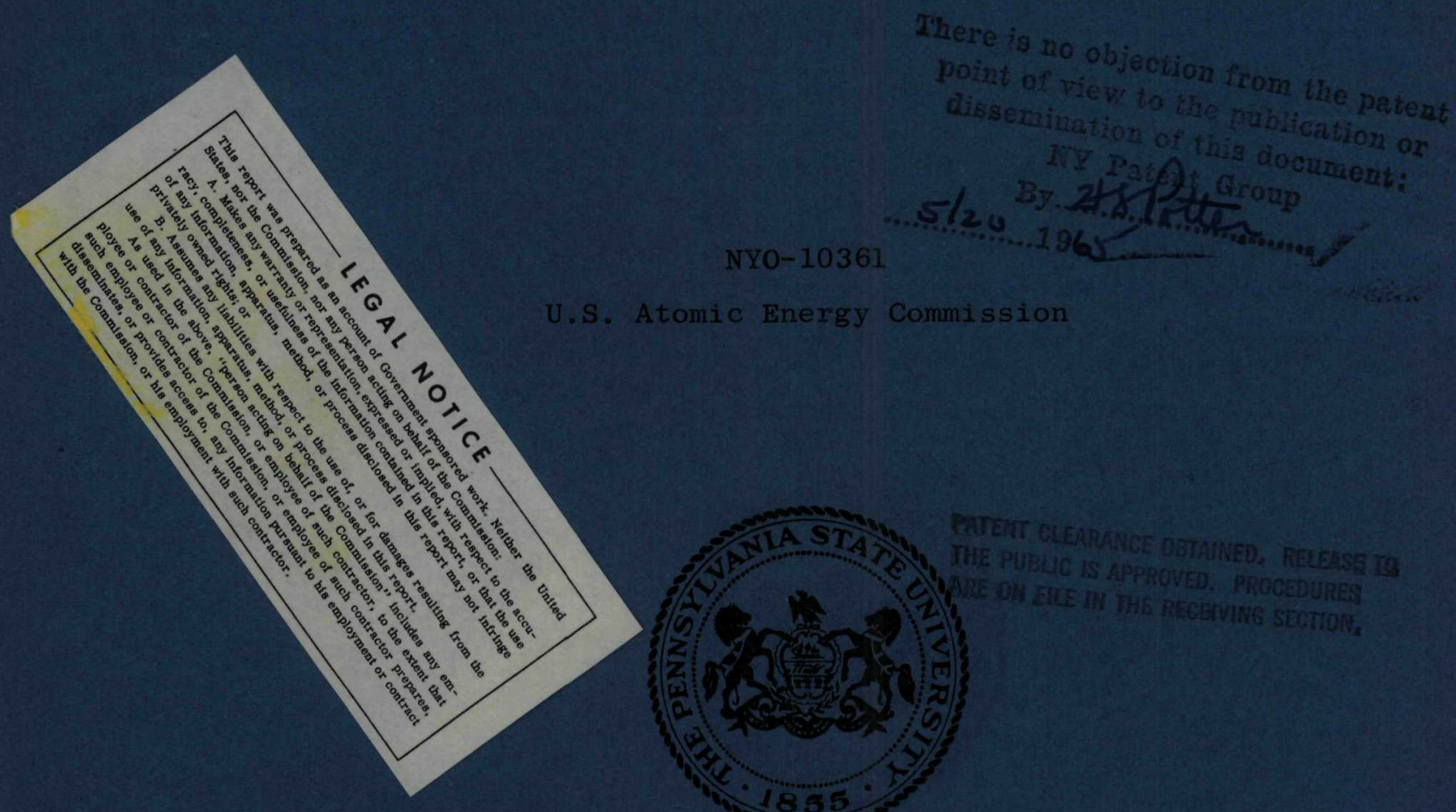

NYO-10361

.S. Atomic Energy Commission

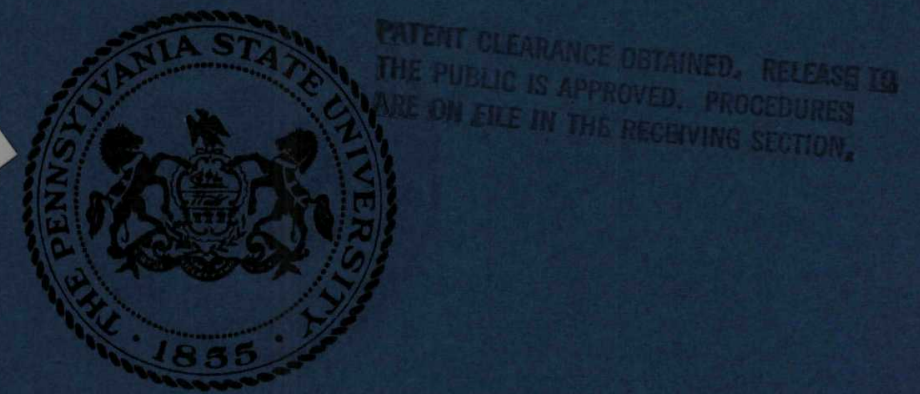

University Park, Pennsylvania 


\title{
PENNSYLVANIA'S \\ COLLEGE OF MINERAL INDUSTRIES \\ FIELDS OF WORK
}

\author{
Earth Sciences \\ Geology - Mineralogy - Geophysics - Geochemistry - Meteorology - Geography \\ Mineral Engineering
}

Mineral Economics - Mining - Mineral Preparation - Petroleum and Natural Gas

\author{
Mineral Technology \\ Ceramic Technology - Fuel Technology - Metallurgy
}

\section{Analytical and Structural Studies}

Silicate and Carbonate Rock Analysis - X-ray Crystallography

Electron Microscopy and Diffraction - Instrumental Analysis 


\section{DISCLAIMER}

This report was prepared as an account of work sponsored by an agency of the United States Government. Neither the United States Government nor any agency Thereof, nor any of their employees, makes any warranty, express or implied, or assumes any legal liability or responsibility for the accuracy, completeness, or usefulness of any information, apparatus, product, or process disclosed, or represents that its use would not infringe privately owned rights. Reference herein to any specific commercial product, process, or service by trade name, trademark, manufacturer, or otherwise does not necessarily constitute or imply its endorsement, recommendation, or favoring by the United States Government or any agency thereof. The views and opinions of authors expressed herein do not necessarily state or reflect those of the United States Government or any agency thereof. 


\section{DISCLAIMER}

Portions of this document may be illegible in electronic image products. Images are produced from the best available original document. 
UNCLASSI FIED

Final Research Report

Contract No. U.S.A.E.C. At (30-1)-2000

AN INVESTIGATION OF THE

MINERALOGY, PETROGRAPHY AND PALEOBOTANY

OF

URANIUM-BEARING LIGNITES

Submitted by

T.F. Bates and W. Spackman

to the

U.S. Atomic Energy Commission

May 1, 1965

College of Mineral Industries The Pennsylvania State University University Park, Pennsylvania

UNCLASSI FIED 
$\underline{\text { Table }}$ of Contents

Page

I. Statement of objectives $\ldots$

II. Summary Description of Total Effort -

III. Summary of the Research Program

A. Aims --

B. Plan and Procedure - 6

C. Results -

Area I - Mineralogy of Western Lignites and Related Sediments -- -

Area II - Autoradiography -

Area III - Chemistry of Western Lignites and Related Materials -

Area IV - Petrography of Western Lignites and Related Materials --_--_---- 24

Area V - Palynology of Dakota Lignites ----- 27

Area VI - Modern Phyto-organic Sediments and Sedimentary Environments - - - - - - 33

IV. Summary of Other Contributions of the Program -

A. Publications and Reports - 36

B. Theses -

C. Papers Presented at Scientific Meetings ------- 40

D. Undergraduate and Graduate Training and Support -- 42

E. Technique Development -

F. Development of the Mineral Constitution Laboratories -- 
Page

G. Development of the Organic Sediments

Laboratory - 46

V. References - 46 


\section{Statement of Objectives}

As is the case for all research performed in a university, the major objectives of this program have been (1) to obtain new knowledge, and (2) to improve and promote the education of research specialists.

The knowledge sought includes (1) a deeper understanding of the system under investigation - in this case the mineralogy, petrography and paleobotany of uranium-bearing lignites - and (2) information pertaining to new techniques and procedures.

The education of research specialists involves primarily the training of students at various stages of their college career: undergraduate, graduate and post-doctoral. In addition, however, good research programs provide important opportunities for the professional growth of the scientific and professional personnel and for the development of laboratories and facilities that support this growth and that of the institution as a whole.

The Atomic Energy Commission, in its sponsorship of the program summarized herein, has provided significant support of these objectives.

II. Summary Description of Total Effort

Following a year of work 1 nitiated in 1951 on the investigation of the mineralogy, petrography and chemistry of uranium-bearing shales, it was suggested by representatives of the Commission that a similar effort on the iignites of South Dakota might be appropriate in the light of increasing interest in these materials as a potential source of uranium. cionsequently, in ApriI 1952 the research effort support at that time under contract No. At (30-1)-1202. was divided into Scope A - Shales, and Scope B - Lignites, and the total program was increased appropriately in size to cover the 
additional work.

In 1957 it became evident that the lignite portion of the work could be more easily handled under a separate arrangement and contract No. At (30-1)-2000 was initiated. This constitutes the final report on that contract。

From the beginning it was appreciated that the answers to questions about uranium in lignite involved detalled study of two very different types of material: the lignite itself and the mineral matter surrounding and enclosed in it. For this reason, responsibility for the program was shared by T.F. Bates, Professor of Mineralogy and William Spackman, Professor of Palleobotany。

Studies were initiated in the summer of 1952 with field sampling at the Mendenhall strip mine in the Slim Buttes area near Buffalo, South Dakota. By the summer of 1954, detailed field sampling, in some cases involving extensive bulldozing operations, had been extended to several other slim Buttes sites. Reconnaissance studies had also been made at many locations In the Williston Basin, in several other major lignite deposits in the West: and at modern swamp environments in the Everglades and the Okefenokee Swamp. Ultimately, the sampling program was extended to include detailed work at many other South Dakota sites, at California deposits, and at a large number of sites in the Everglades.

Laboratory work followed a similar history of development and expansion appropriate to the increasing numbers of samples being supplied. Although the previously initiated research on uranium in black shales had resulted in the development of "know-how" pertinent to the study of one type of mireral-organic system, the lignite presented many new problems 
with respect to initial sampling, specimen preparation, and instrumental and chemical evaluation. The treatment and solution of these problems, the data obtained, and the interpretations made therefrom are dealt with in the various reports and publications emanating from the research program. Suffice it to say here that during the "history" of the project, the work passed from the exploratory stages concerned with "What to measure" and "How best to measure it" to standardization of test methods and statistically controlled sampling and data evaluation. By the completion of the project some 2,657 samples had been analyzed for up to 36 chemical elements, autoradiographed, evaluated for spoxe and pollen content, subjected to petrographic evaluation, and "looked at" in varying degrees with all the instruments available in unusually we11-equipped mineralogy, palynology and coal petrography laboratories. This analytical program is detailed in Table

participating in and receiving an important part of their education from the study were some 50 undergraduates and 40 graduates. In addition, two post-doctoral Research Associates participated in the project. of the graduate assistants, 5 completed M.S. theses and 2 completed Ph.D. theses on project research.

Papexs presented at national scientific meetings amounted to 18 and 32 technical reports and scientific publications have resulted.

Project support had a great deal to do with the growtn of two permanent laboratory units of the College of Mineral Industries, namely the Mineral Constitution Laboratories and the Organic Sediments Laboratory. These have become widely known as outstanding examples of faclijties developed for the support of mineral and coal research. 
Table 1

Compilation of Main Analytical Program Samples

\begin{tabular}{|c|c|c|c|c|c|c|c|}
\hline \multirow{2}{*}{$\begin{array}{c}\text { Site } \\
\text { Designation }\end{array}$} & \multicolumn{7}{|c|}{ Number of Samples Analyzed } \\
\hline & Chemically & $\begin{array}{c}\text { Radio- } \\
\text { metrucally }\end{array}$ & $\begin{array}{c}\text { Spectro- } \\
\text { chemically }\end{array}$ & $\begin{array}{c}\text { For Ash } \\
\text { Yield }\end{array}$ & $\begin{array}{c}\text { Petro- } \\
\text { graphically }\end{array}$ & $\begin{array}{l}\text { Phyteral- } \\
\text { lcally }\end{array}$ & $\begin{array}{l}\text { Palyno- } \\
\text { logically }\end{array}$ \\
\hline \multicolumn{8}{|l|}{ North Dakota } \\
\hline $\begin{array}{l}\text { Lutheran Church } \\
\text { Property }\end{array}$ & 122 & & & & 36 & 19 & 19 \\
\hline Golden Valley & & & & & & & 7 \\
\hline \multicolumn{8}{|l|}{ South Dakota } \\
\hline Mendenhal 1 Cut & & 21 & & & 124 & & 57 \\
\hline $\mathrm{SD}-1$ & 170 & 26 & 26 & 26 & 128 & 18 & 267 \\
\hline Cedar Canyon & 18 & 18 & & & 18 & 18 & 18 \\
\hline Flint Butte & 21 & & & & & & \\
\hline Hilltop Claim & 9 & & & & 6 & 10 & 10 \\
\hline Jim \#1 Claim & 14 & & & & & & 14 \\
\hline Jensen Claim & 13 & & & & 9 & & 14 \\
\hline $\begin{array}{l}\text { Lonesome Pete } \\
\text { Claim }\end{array}$ & 18 & & & & 18 & 18 & 18 \\
\hline Pickpocket Claim & 15 & & & & & & 15 \\
\hline Rolf $\mathrm{Claim}$ & 11 & & & & 11 & 11 & 11 \\
\hline Trio Claim & 18 & & & & & & 18 \\
\hline Mendenhall Valley & 15 & & & & & 15 & 15 \\
\hline $\begin{array}{l}\text { Cave Hills, Twin } \\
\text { Butte and Crow } \\
\text { Butte }\end{array}$ & & & & & & & 116 \\
\hline SD-11, SD-22, SD-32 & & & & & & & 142 \\
\hline
\end{tabular}


Table 1 (cont.)

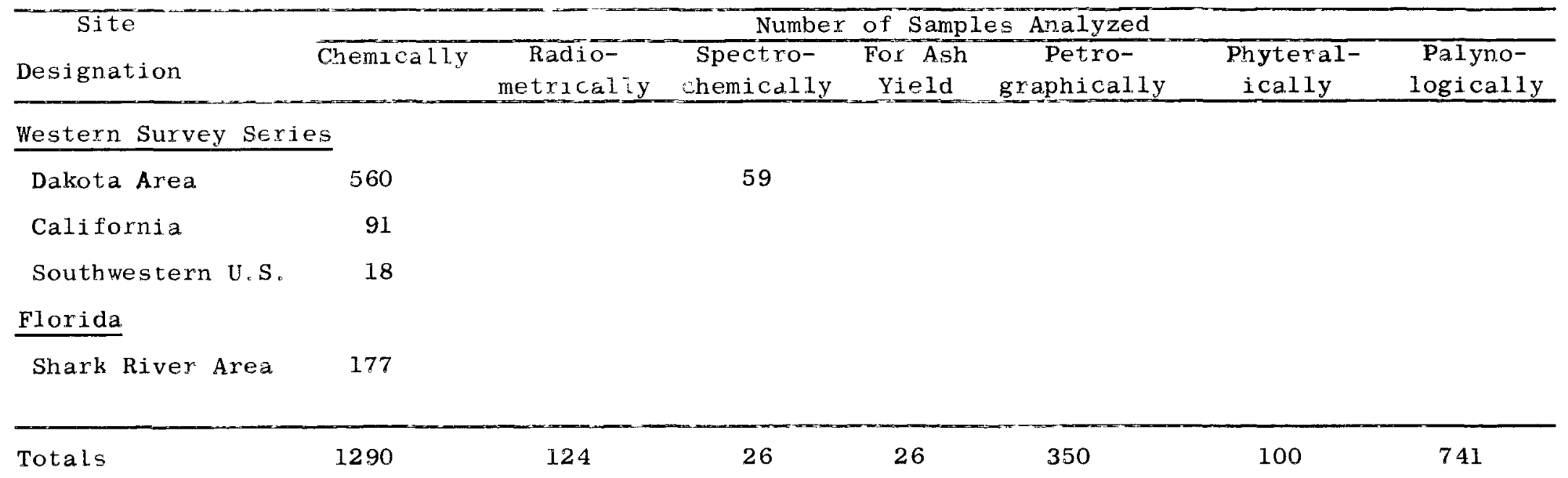


Firally, 1 t is important to point out that research initiated on this project on modern organic sediments set the stage for contınued work now supported by the National. Science Foundation. A measure of the significance of and irterest in this research is evidenced by the decision to include a trip through the Everglades, conducted by Dr. Spackman, as one of the annual field excursions of the Geological Society of America.

III. Summary of Research Program

\section{A. Aims}

The research summarized herein was conducted for the purpose of obtaining useful information concerning:

1. the nature of the uranium complex or complexes in uraniferous lignites;

2. the manner in which the uranium complex is held in the rock mass, and as a corollary, the ease with which it can be removed:

3. the parameters that control the precipitation, distribution and retention of uranium;

4. the specific role played by carbonaceous matter and the relationship of the petrographic characteristics of the orgaric matter to uranlum distribution;

5. the geological conditions that promote the concentration of uranium in rocks of this type, and

6. geological, mineralogical, petrogxaphic and paleobotanical criteria

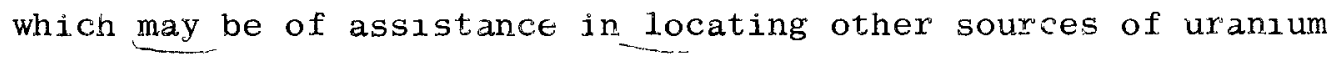

\section{B. Plan and Procedure}

The nature of the material to be studied dictated from the start that, to provide the data pertinent to the hoped for realization of the above objectives, the investigation would have to involve a combination of the 
paleobotanical and palynological approach with the geochemical and mineralogical one. With the passing of the exploratory phase of the investigation, the many areas of work were resolved into six major efforts, as follows:

Area I: Mineralogy of western lignites and related sediments

Area II: Autoradiography

Area III: Chemistry of lignites and related materials

Area IV: Petrography of western lignites and related sediments

Area V: Palynology of Dakota lignites and related sediments

Area VI: Modern phyto-organic sediments and sedimentary environments.

Responsibility for the research encompassed by areas I to III was held by the mineralogical group under the direction of T.F. Bates, whereas the paleobotanists and palynologists under the direction of W. Spackman were responsible for most of the work in areas IV to VI. Complete interaction between the groups was maintained throughout the program with both field and laboratory studies representing combined efforts of both groups.

Chrorologically speaking, the first three years of the program (19521955) were devoted to the field study, sampling, and laboratory evaluation of Dakota lignite samples. Analysis of the resulting data made it evident that a more meaningful evaluation of the Dakota situation could be made by conducting a collateral investigation of a modern swamp environment where the initial steps in the process of coal formation in the presence of uranium-bearing solutions could be studied. In consequence, after appropriate evaluation of various possibilities, work was initiated in the summer of 1955 on peat material collected from the Floxida Everglades. In the remaining years of the program, an increasingly extensive research 
investigation was carried out in this area, and with the termination of A.E.C. sponsorship, continued support has been provided to the present by the National Science Foundation.

In 1958 work was also started on lignite of Eocene age from the Ione formation of Californiag in order to provide comparable information on the nature of inorganic-organic relationships in non-uraniferous coal similar in other respects to that in the Dakotas.

As the above statements indicate, nine years of research effort has involved work on a large number of deposits in North and South Dakotay one area in California, and many sampling localities in the Florida Everglades. Detalis on these specific locations will not be given here but are avallable in the reports listed herein.

\section{Results}

$\underline{\text { Area }} I-\underline{\text { Mineralogy }}$ of Western Lignites and Related Sediments

The mineralogy of the various Dakota lignite deposits is simple to complex, depending upon the existence and amount of secondaxy mineralızation. In deposits like Mendenhall and SD-1, the minerals present consist largely of detrital varietıes such as quartz, mica, occasional feldspar and some of the clay, authigenic material such as pyrite and appreciable kaolinite; and, depending on the degree of weathering, variable amounts of jarosite and gypsum. In other deposits (Cave Hills, Trio, $\in$ tc.) where percolating solutions have had more effect, secondaxy uxanium minerals, radioactive barite, and analcite are also found in varying concentrations. In the California lignite studied for comparison purposes, quartz, kaolinite, pyrite, gypsum and one occurrence of jarosite were found. 
Detailed studies of clay mineralogy revealed interesting differences between lignite beds and associated clay seams (see for example NYo-6061 pp. 32-48; and NYO-6069 pp. 60-65). The clay minerals allophane, halloysite (metahalloysite), illite, montmorillonite and mixed layered clays have been identified in both the clastic and lignite beds. Minor amounts of chlorite and vermiculite were found in some samples of shale. Montmorillonite and illite are the predominant minerals in the clastic beds while kaolinite is a subordinate constituent. On the other hand, kaolinite and illite are the predominant clay minerals in the lignite while montmorillonite occurs only in minor proportions. It is of interest that whereas the clay in layers and disseminated throughout the lignite is kaolinite and illite, that found in stringers and veinlets believed to be of secondary origin is chiefly kaolinite with subordinate amounts of allophane and halloysite. Much of the kaolinite in the lignite appears to be authigenic and is characterized by poorly formed flakes a few tenths of a micron in size and by x-ray data indicating a b-axis disorder. Its presence is indicative of silica- and alumina-containing solutions present during the formation of the coaly material. The scarcity of montmorillonite in the coal may be attributed either to non-deposition or to partial destruction by leaching during or after the formation of the lignite. The paucity of detrital clay material in the lignites is indicative of the flat terrain and chemical environment possibly similax to that now exemplified by the Florida Everglades where detrital sediments are equally scarce. Most of the lignite deposits studied have been deeply weathered (even where the seams are covered by 100 feet or more of overburden). A mineralogical result of the process has been the formation of numerous hydrous 
sulphites of ferric iron and alkalies belonging to the jarosite group.

In a thesis done on the project, Mr. Geroge Savanick (1961) has provided

detailed descriptions of the mineralogy, chemistry, structure and properties

of the various mineral varieties, and has described their occurrence in

the lignite seam and their relationship to the other minerals present.

The following excerpt from the thesis summary details some of the more

significant findings:

"Extensive isomorphous substitution and possibly some adsorption

of elements causes the chemistry of individual samples (of jarosite)

to differ in detail. Potassium, sodium, calcium, strontium, and ammonium appear to reside in the twelve-fold coordinated structure sites. Major amounts of aluminum and lesser concentrations of titanium, molybdenum, manganese, magnesium, copper and nickel substitute for sulfur in the tetrahedral sites. It is uncertain whether or not uranium resides in the octahedral sites in the structure or is adsorbed onto the surface of the jarosite. The $\mathrm{U}^{+6}$ ion, which is the oxidized state of uranium, could fit easily into the octahedral sites if uncomplexed, but the $\left(\mathrm{UO}_{2}\right)^{2+}$ complex ion, which is often found in acidic-oxidizing groundwater, is too large to fit in the structure and must therefore be adsorbed onto the surface of the mineral.

The chemistry, mode of occurrence, and genesis of the jarosite appear to be related. Nodules of jarosite, which appear to be the products of in situ weathering of pyrite, have very limited substitution for iron in the octahedral sites. Extensive substitution for iron is found in those jarosites which coat and impregnate the lignite along fractures where they probably precipitated from percolating groundwater. Chemistry is also related to density in that the high-aluminum samples are much less dense than the lowaluminum jarosites.

Radioactivity, ranging from $0.006 \%$ equivalent uranium was detected in jarosite from thirteen of the fifteen deposits studied. Uranium is present in some of the jarosites but a large disparity in the chemical uranium versus the equivalent uranium values, coupled with the fact that radium-bearing barites are adjacent to the radioactive jarosites, indicates that radium also accounts for some of the radioactivity.

It is probable that all of the jarosite originated, either directly or indirectly, by the decomposition of pyrite. Jarosite is found altering directly from pyrite in some of the less weathered deposits. However, most of the lignites have been so severely weathered that no pyrite remains and the jarosite occurs either as the cores of limonite-encrusted nodules or as stringers in the lignite where it appears to be intermixed with and possibly altering 
to limonite. The final stage of this weathering of pyrite through jarosite to the usual ultimate product, limonite, appears to be represented in the $\mathrm{Klym}$ deposit where the jarosite nearly disappears and the limonite becomes predominant."

of greater interest from the standpoint of the uraniferous nature of the deposits, are the minerals formed from solutions percolating through the lignitic materials during or subsequent to their formation. These were studied in great detail by Mr. Eugene White and the results appear in his M.S. thesis "Uranium mineralization in some North and South Dakota lignites" (1958 and NYO-7948). Since this work was an inherent part of the total mineralogical program, the results given in White's summary are reproduced here.

"It has been determined that of the twelve (uranium) minerals from the eleven deposits studied, eleven minerals belong to the torbernite-metatorbernite series of hydrous uranium arsenates and phosphates. A twelfth mineral, containing at least uranium and sodium as major constituents, is believed, on the basis of $x$-ray diffraction data, to be a new mineral. Seven species of the torbernite-metatorbernite series have been recognized and include: sodium-autunite $\mathrm{Na}_{2}\left(\mathrm{UO}_{2}\right)_{2}\left(\mathrm{PO}_{4}\right)_{2} \cdot 8 \mathrm{H}_{2} \mathrm{O}$, meta-uranocircite $\mathrm{Ba}\left(\mathrm{UO}_{2}\right)_{2}$ $\left.\left(\mathrm{PO}_{4}\right)_{2} \cdot 8 \mathrm{H}_{2}\right)$, meta-autunite $\mathrm{Ca}\left(\mathrm{UO}_{2}\right)_{2}\left(\mathrm{PO}_{4}\right)_{2} \cdot 6-8 \mathrm{H}_{2} \mathrm{O}$, saleeite $\left.\mathrm{Mg}\left(\mathrm{UO}_{2}\right)_{2}\left(\mathrm{PO}_{4}\right)_{2} \cdot 1 \mathrm{H}_{2} \mathrm{O}\right)$, sabugalite-saleeite (?) (HAI) $\left(\mathrm{UO}_{2}\right)_{4}\left(\mathrm{PO}_{4}\right)_{4} \cdot 16 \mathrm{H}_{2} \mathrm{O}$, hydrogen-autunite $\left.\mathrm{H}_{2}\left(\mathrm{UO}_{2}\right)_{2}\left(\mathrm{PO}_{4}\right)_{2} \cdot 8 \mathrm{H}_{2}\right)$ and abernathyite $\mathrm{K}_{2}\left(\mathrm{UO}_{2}\right)_{2}$ (AsO $\left.{ }_{4}\right)_{2} \cdot \mathrm{HH}_{2} \mathrm{O}$. Of these, sodium-autunite, which heretofore had not been reported in this country, was found to be the most common and abundant species. It was found in four deposits and varied slightly in chemical character, suggesting a possible solid solution series with the $\mathrm{Ca}$ and $\mathrm{H}$ end members.

The dehydration characteristics of the uranium minerals are related to the size of the exchangeable cation in the structure. It was determined that the small $\mathrm{Mg}^{++}$and the $\mathrm{Al}^{+++}$ions produce only two hydration states where the lower hydrate corresponds to the highest obtainable for the large $\mathrm{Ba}^{++}$and $\left(\mathrm{H}_{3} \mathrm{O}\right)^{+}$(?) ions. The intermediate sized $\mathrm{Na}^{+}$and $\mathrm{Ca}^{++}$ion produce the most complex results involving four to five hydration states where the highest hydration state corresponds to the highest for the $\mathrm{Mg}^{++}$and the $\mathrm{Al}^{+++}$while the lowest hydration state corresponds to the lowest, hydrate for the large $\mathrm{Ba}^{++}$and $\left(\mathrm{H}_{3} \mathrm{O}\right)^{+}$ions. 
Most deviations in the properties of the uranium minerals described in this study from the properties given in the literature for the same species can be explained on the basis of chemical substitution. Arsenic replaces on the order of $10 \%$ of the phosphorus in seven of the minerals. Partial substitution of hydrogen for sodium, calcium for sodium, magnesium for aluminum, and aluminum for hydrogen may explain some of the observed variations.

The uranium minerais were not seen to have an affinity for a given lignite maceral. A blocky character of the lignite, however, does favor uranium mineral formation. Where uranium minerals are present on these block surfaces they cover the various macerals indi scriminately.

The high solubility of the lignites in the Rolf, Billy Dale, Al \#2 and Trio deposits together with the lack of pollen and spores indicates that the lignite has been subjected to alkaline, oxidizing solutions at ore time or another. This is further corroborated by the occurrence of a viscous organic liquid in portions of the Trio deposit. Sodium-autunite is the only uranium mineral found in each of these deposits. It is believed that in some manner the formation of the sodium-autunite relates to the factors that caused the unique character of the organic material.

The common non-detrutal minerais are gypsum, iarosite, barite and analcite. The barite is invariably radioactive due to the presence of radium. Its radioactivity and paragenetic relationships with the uranium minerals in many of the deposits suggest recent deposition of the uranium (see Stern and Streff, 1956). On the basis of fieid and laboratory studies, a paragenetic sequence has been proposed which related the components in the following order: a) similtaneous deposition of the lignite and inorganic detritus, b) pyrite formation during deposition of the oxganic material and following burial, c) analcite, jarosite and gypsum formation with gypsum and jarosite deposition probably continuing to the present, d) radioactive barite and the uranium mineral deposition possibly continuing to the present in some instances.

The etched appearance of the analcite in the vicuntty of the uranium minerals suggests the zeolite to be the source of sodium for the sodium-autunite. Since the only occurrence of the $\mathrm{Mg}$ and Al. mineral. varieties were found in the only two clayey samples, it is thought that these elements were furnished at the expense of the clay minerals.

$$
\text { Although such ions as the }\left(\mathrm{SO}_{4}\right)^{=},\left(\mathrm{CO}_{3}\right)^{=},\left(\mathrm{AsO}_{4}\right)^{3-} \text { and }\left(\mathrm{SiO}_{4}\right)^{4-}
$$

were probabiy in the ground water at the time of the uranium mineral formation, the uranium is, with one exception, found to be complexed with the $\left(\mathrm{PO}_{4}\right)^{3-} . \mathrm{Ca}^{++}, \mathrm{Ba}^{++}, \mathrm{Na}^{+}, \mathrm{K}^{+}, \mathrm{H}^{+}$or $\left(\mathrm{H}_{3} \mathrm{O}\right)^{++}, \mathrm{Mg}^{++}$and $\mathrm{Al}$ commonly occurr as the excrangeable cations in the mineral structures.

The uranium mineral occurrences can be subdivided into three groups on the basis of the geographical area and stratigraphic horizons in which they occur. The stratigraphy and geography are interdependent. The uranium mineral formation in a given uraniferous lignite deposit seems to be confined to the rear-outcrop portions 
of the lignite or where the overburden is less than about 30 feet.

It is concluded that it is possible in some cases for the uranium minerals to have been precipitated directly from solutions having their origin in the volcanic source beds. However, the minerals more commonly result from secondary movement of the uranium within the lignite seams. The particular uranium mineral in a given lignite seam formed by this leaching and redeposition process does not depend directly upon the chemistry of the original uranium-bearing solutions but depends primarily upon the existing mineralogy and the chemistry at the point of the mineral deposition."

\section{Area II - Autoradiography}

Alpha track autoradiography was used throughout the study as an extremely useful technique for providing information on the quantities, distribution and nature of radioactive material in the samples. Continuing attempts to use fission fragment radiography to discriminate uranium from thorium and from the daughter products of each (Bates, Wright and Skipper, 1958) did not prove satisfactory because of problems with the variable sensitivity of Eastman NTC emulsion to gamma radiation.

The autoradiography studies very soon made it clear, and chemical determinations corroborated, that the uranium exists in two radically different ways in the lignite: 1) as ions presumably adsorbed or complexed with the organic material, and 2) in the form of uranium minerals. Uranium of the first type is revealed in autoradiographs by tracks (usually single) disseminated throughout the coal. Uranium minerals, even of very fine particle size, give rise to clusters of tracks radiating outward from the same source - whether it be of large or small dimensions.

Alpha track studies were completed on 423 samples from eight deposits of Dakota lignite. The greatest differences revealed by the study lie not only in the total number of tracks per unit exposure time (reflecting the variation in uranium content between samples) but also in the microscopic 
distribution of "disseminated" tracks and track clusters.

As is to be expected, there is a positive overall relationship between $\% \mathrm{U}$ and total number of tracks but the deviation from a "1:1" correspondence is very large due to the fact that most of the samples are not in radioactive equilibrium。

The proportion of clusters to disseminated tracks varies widely but certain general relationships are of considerable significance from the standpoint of origin and distribution of the uranium.

1. Samples low in uranium have few, if any, clusters.

2. Samples high in uranium may or may not show a large proportion of clusters in relation to number of disseminated tracks.

3. Clisters are sometimes concentrated along irregular "paths" across the lignite fragments or along fragment edges, supporting other evidence that daughter products and uranium minerals are deposited from solution along fissures through the coal.

4. For similar reasons clusters are rare within the larger, presumably less weathered, chunks of blocky lignite.

5. In these same chunks, however, the number of disseminated individual. tracks may be high, suggesting that uranium ions are distributed in large numbers throughout the material.

The influence of textural features on uranium distribution was also studied in an investigation of an unweathered lignite at the Lutheran Church deposit in Billings. County, North Dakota. Although the uranium was determined chemically, the results are pertinent to the foregoing statements. This lignite has an extremely well developed vertical joint system resulting in the development of polygonal columns of lignite. One such column 
measuring about 2.5 feet in diameter was sampled (summer 1957) so that the influence of jointing on the distribution of uranium could be studied. One hundred and seven samples from one two-inch level in the block were analyzed for uranium. These samples represented two sub-levels from which oriented blocks were taken at various distances away from the joint faces toward the center of the block.

Sixteen of the samples were bounded on one side by a joint face and in 14 cases the sample facing the joint had a lower uranium content than the one immediately behind (toward the center). An additional but less pronounced trend is that after the initial increase in uranium content, there is a general decrease in uranium toward the center of the polygon. These observations may indicate that the uranium was originally deposited by solution passing along the joints causing the uranium content to be highest at the joint face. Subsequent leaching of the uranium from the lignite closest to the joint then produced the now observed trend. The uranium thus leached could provide the uranium now found in the form of secondary uranium minerals in the near-surface weathered zone.

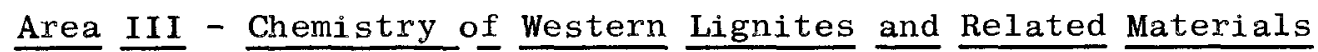

Chemical work on the project was continuous since its inception and included analyses of not only the lignites but various fractions and segregates therefrom as well as non-lignitic materials associated with the coal seams. Extensive analytical work was also done on the peats and associated sediments from Florida and on numerous grab samples demonstrating organic-inorganic relationships of possible significance to uranium precipitation and accumulation. Most of the analyses have been published in technical reports (NYO-7949 and NYO-7950) and are discussed in the reports and theses resulting from 
project work. The following information simply represents an attempt to summarize material of major interest.

A total of 546 samples were analyzed for uranium and the following major constituents: moisture, carbon, hydrogen, ash, total sulfur, sulfate sulfur, total iron, silicon, aluminum, calcium, magnesium, and uranium. The number of samples and average values for each of the four geographic areas involved are given in Table 2. It is apparent that the outstanding difference between the California and Dakota samples lies in uranium content. The Florida samples are peat which, because of the association with carbonate material,

Table 2

Average Values Determined for the

Dakota, California, Florida and Southwest Samples

\begin{tabular}{lcccccc}
\hline & $\begin{array}{c}\text { No. of } \\
\text { Samples }\end{array}$ & C & H & Ash & $\begin{array}{c}\text { Sulfate } \\
\text { Sulfur }\end{array}$ & $\begin{array}{c}\text { Total } \\
\text { Sulfur }\end{array}$ \\
\hline Dakota & 423 & 40.81 & 2.36 & 34.21 & 0.44 & 1.59 \\
California & 91 & 33.89 & 2.86 & 43.11 & 0.86 & 2.58 \\
Florida & 14 & 38.59 & 3.55 & 29.48 & 0.27 & 1.72 \\
Southwest & 18 & 26.10 & 2.21 & 61.12 & 0.32 & 8.53 \\
\hline
\end{tabular}

\begin{tabular}{lcccccc}
\hline & $\begin{array}{c}\text { Total } \\
\text { Iron }\end{array}$ & \multicolumn{1}{c}{$\mathrm{Si}$} & $\mathrm{Al}$ & $\mathrm{Ca}$ & $\mathrm{Mg}$ & $\mathrm{U}$ \\
\hline Dakota & 4.85 & 6.24 & 2.34 & 1.39 & 0.34 & 0.2151 \\
California & 2.83 & 10.22 & - & 0.47 & - & 0.0008 \\
Florida & 1.08 & 3.16 & - & 7.30 & 3.64 & 0.0008 \\
Southwest & 6.89 & 14.07 & - & 0.52 & - & 1.7667 \\
\hline
\end{tabular}

have more $\mathrm{Ca}$ and $\mathrm{Mg}$. Samples from the "Southwest" were collected from a number of localities in Utah and New Mexico where uranium is enriched in sediments containing various types of organic material such as asphaltite, logs, and "carbonaceous trash". The high uranium content is explained on the 
basis of biased sampling, and the high ash content is to be expected in samples of this type.

For the Dakota lignites, simple and multiple linear regression statistics were used to analyze the samples from (1) Cave Hills, (2) North Dakota, (3) Slim Buttes and (4) all localities combined.

The simple correlations with uranium are tabulated in Table 3 . The correlations which are significant at the $1 \%$ confidence level are marked with two asterisks while those significant only at the $5 \%$ level are marked with one asterisk。

Table 3

$\underline{\text { Simple } \text { Correlation Coefficients }}$

\begin{tabular}{|c|c|c|c|c|}
\hline $\mathrm{U}$ versus & Cave Hills & North Dakota & Slim Buttes & Combined \\
\hline Moisture & NS & NS & $=.35 * *$ & NS \\
\hline Carbon & $-.41 * *$ & $-.25 *$ & $-.18 *$ & $-.33 * *$ \\
\hline Sulfate SuIfur & $-.62 * *$ & NS & NS & $-.29 * *$ \\
\hline Total Sulfur & $-.59 * *$ & NS & NS & $-.27 * *$ \\
\hline Hydrogen & $-.33 * *$ & NS & NS & $-.24 * *$ \\
\hline Ash & $+.41 * *$ & $+.21 *$ & $+.26 * *$ & $+.36 * *$ \\
\hline Silica & t. $39 * *$ & NS & $-.26 * *$ & $+.30 * *$ \\
\hline Calcium & NS & NS & $-.23 *$ & NS \\
\hline Total Iron & NS & NS & $-.21 *$ & NS \\
\hline$U-E q \cdot U$ & NS & $+.47 * *$ & $+.47 * *$ & $+.12 *$ \\
\hline
\end{tabular}

Note that in every case the simple correlation of ash versus uranium is positive and significant. The North Dakota group is the only one not showing a significant correlation of uranium with silica. Note, also, that within the carbonaceous horizons in every case the carbon is negatively correlated with uranium。

Table 4 lists the values for the multiple correlation coefficients, $R$, 
Table 4

Multiple Correlation Coefficients

Cave Hills North Dakota SlimButtes

\begin{tabular}{|c|c|c|c|c|}
\hline Multiple $\mathbf{R}^{2}$ & .63 & .39 & .67 & .31 \\
\hline Multiple $R$ & .79 & .62 & .82 & .56 \\
\hline $\begin{array}{l}\text { Significant } \\
\text { Variables }\end{array}$ & $\begin{array}{l}\text { M, C, Sulf. S, } \\
\text { Si, Total Fe }\end{array}$ & $\mathrm{C}, \mathrm{U}-\mathrm{Eq} \cdot \mathrm{U}$ & $\begin{array}{l}\text { M, Total S., } \\
\text { Ash, Si, Ca, } \\
\text { Total Fe, } \\
\text { U-Eq. U }\end{array}$ & $\begin{array}{l}\text { M, C, Sulf. S, } \\
\text { Ash, Si, Ca, } \\
\text { Total Fe, } \\
\text { U-Eq. U }\end{array}$ \\
\hline
\end{tabular}

along with the corresponding $\mathrm{R}^{2}$ 's, for each of the groups. Also listed are the variables which are found to explain a significant amount of the variation in uranium.

In the case of the combined samples only $31 \%\left(\mathrm{R}^{2} \times 100\right)$ of the variation of uranium was explained. Grouping the data on the basis of the three areas results in the explanation of a larger percentage of the variation for each individual area. The greatest increase in the explained variation as a result of grouping the data is the Slim Buttes area where a total of $67 \%$ of the variation is explained. Sixty-three percent of the variation is accounted for in the Cave Hills groups while only $39 \%$ of the variation is explained for the North Dakota samples. The results indicate that the grouping of all the samples into one problem is, in effect, mixing populations. This is further suggested by the fact that different sets of variables explain the variation of uranium content within the separate groups. For example, the percent carbon along with the measure of disequilibrium $(\% \mathrm{U}-\% \mathrm{Eq}$. U) together account for the variation with uranium in the North Dakota samples. This contrasts with the Slim Buttes area where moisture, total sulfur, ash, silica, calcium, total iron and uranium minus equivalent uranium all are significant in explaining the variation in uranium. 
In the California samples the percent uranium correlates positively with the percent ash and in this respect the material is very similar to the Dakota material. In contrast with the Dakotas, the iron content in the California lignite is very low and there is no sulfate sulfur.

In addition to the analysis of major constituents discussed abave, 100 of the samples from the Dakotas and California were analyzed for 21 trace elements. Table 5 compares the concentration of elements in these samples with that in coal ash and with the average concentration in the earth's crust. It is evident that in addition to minor differences, there is a notable enrichment in the lignite of Mo and a "deficiency" of PB and Sn. Statistical evaluation of the trace element data from 62 of the Dakota samples has provided very useful information as to the probable nature of the chemistry of the uranium-bearing solutions. The following conclusions seem to be justified by the available data on trace and major element concentrations:

a) the solutions which entered the lignites were oxidizing and the pH was probably weakly acidic to weakly alkaline;

b) abundant sodium was a factor in maintaining the pH at a level which not only tended to form uranium minerals, but also to fix uranium by adsorption. A negative correlation of uranium with total sulfur indicates that the sulfur available to produce strongly acidic solutions would have an inhibiting effect if it were present in amounts greater than could be neutralized by the sodium or other sulfate forming elements;

c) a negative correlation with manganese suggests that this element was not present in the oxidizing solutions entering the lignites, 
Table 5

Trace Element Concentration in

Lignite, Coal Ash, and the Earth's Crust

\begin{tabular}{|c|c|c|c|c|}
\hline Element & $\begin{array}{c}\text { Dakota Lignite } \\
\text { Ash, } \%\end{array}$ & $\begin{array}{c}\text { California } \\
\text { Lignite Ash } \\
\% \\
\end{array}$ & $\begin{array}{l}\text { Accumulation } \\
\text { in Coal Ashes* }\end{array}$ & $\begin{array}{l}\text { Earth's } \\
\text { Crust** }\end{array}$ \\
\hline $\mathrm{Sr}$ & 0.17 & 0.12 & - & 0.0300 \\
\hline $\mathrm{Ba}$ & 0.34 & 0.74 & - & 0.025 \\
\hline Ti & 0.34 & 1. 30 & - & 0.44 \\
\hline $\mathrm{Ag}$ & 0.00003 & $<0.00002$ & 0.0002 & 0.00001 \\
\hline As & 0.17 & $<0.005$ & 0.05 & 0.0005 \\
\hline B & 0.045 & 0.0063 & 0.06 & 0.0003 \\
\hline $\mathrm{Be}$ & 0.001 & 0.0005 & 0.03 & 0.0006 \\
\hline $\mathrm{Co}$ & 0.0096 & 0.011 & 0.03 & 0.0023 \\
\hline $\mathrm{Cr}$ & 0.0048 & 0.0073 & - & 0.0200 \\
\hline $\mathrm{Cu}$ & 0.017 & 0.023 & - & 0.0070 \\
\hline $\mathrm{Ga}$ & 0.003 & 0.0029 & 0.01 & 0.0015 \\
\hline $\mathrm{Ge}$ & 0.0084 & 0.0005 & 0.05 & 0.0007 \\
\hline $\mathrm{Mn}$ & 0.031 & 0.077 & - & 0.1000 \\
\hline Mo & 0.48 & 0.0011 & 0.02 & 0.0015 \\
\hline $\mathrm{Ni}$ & 0.021 & 0.057 & 0.07 & 0.0080 \\
\hline $\mathbf{P}$ & 0.60 & N, D. & - & 0.1180 \\
\hline $\mathrm{Pb}$ & 0.004 & 0.0025 & 0.01 & 0.0016 \\
\hline $\mathrm{Sn}$ & 0.0005 & 0.0005 & 0.02 & 0.0040 \\
\hline $\mathrm{V}$ & 0.037 & 0.029 & - & 0.0150 \\
\hline $\mathrm{Zn}$ & 0.043 & 0.032 & 0.02 & 0.0132 \\
\hline $\mathrm{Zr}$ & 0.11 & 0.020 & 0.5 (max.) & 0.0220 \\
\hline
\end{tabular}

N.D. - Not Determined

Unless otherwise noted all values are average values

* Based on values reported by Goldschmidt

** Based on values reported by Mason 
and only the manganese complexed by the plants is found;

d) the separation of cobalt and nickel supports the conclusion that the solutions were oxidizing and slightly alkaline.

Chemical studies of element distribution in the clay seams adjacent to the lignite beds also provided significant information which may be summarized as follows:

1) at a given site the uranium content of the clays tends to be higher for the samples closer to the lignite;

2) in only one case does the uranium content of the adjacent inorganic sample exceed that of the maximum value of $U$ for the lignite seam;

3) in only two cases the $U$ content of the clay sample exceeds the minimum $U$ content of the adjacent lignite seam;

4) in ten cases the maximum $U$ content of the clay seam exceeds the minimum $\mathrm{U}$ content of the lignite bed;

5) the ratio of U/C at a given uranium concentration level is invariably higher for clay samples than in the lignites.

These observations indicate that the inorganic sediments associated with the lignites have in most instances been enriched in uranium, presumably by U-bearing solutions passing through them.

Chemical evaluations were directed at a number of specific problems at various periods throughout the investigation. One such study was that made of the resinoids found in abundance in the lower portion of the Lutheran Church lignite of Billings County, North Dakota. This material was studied in detail by Mr. James Tietjen, using infrared spectroscopy as part of his work for the M.S. degree (1958 and NYO-7947). The following conclusions were reached: 
1) the resinoids are extremely pure - being free of all non-volatile impurities including uranium;

2) the resinoids are primarily resin acids and esters;

3) the resin acids are composed of two major fractions, amber and a form of oxidized abietic acid;

4) the oxidized abietic acid component has undergone self-condensation to form an ester;

5) the condensation probably results in a lower concentration of chromophoric groups.

Finally, numerous chemical studies were made on various fractions isolated from the lignites in efforts to understand better the manner in which uranium is held therein. These investigations involved measurements of $\mathrm{pH}$, surface area, and temperature and oxidation conditions favoring takeup or release of uranium and other cations by (1) the lignite, (2) humic acids extracted from the lignites, and (3) the lignite after humic acid extraction. It is important to point out that in these laboratory experiments, complete saturation with uxanium is involved whereas in the natural situation the amount of uranium supplied was so low that saturated conditions would apply only locally if at all. Nevertheless, the information obtained was extremely useful in the evaluation of the problem at hand.

Three hundred and sixty-eight experimental runs were made to determine the amount of uranium, vanadium,molybdenum, nicke1, cobalt, and arsenic that could be adsorbed. Of the various factors considered pH and surface area appear to be most critıcal. Figure 1 shows the relationships of $\mathrm{pH}$ to take-up of uranium, vanadium and nickel by bulk lignite ground to 100 mesh. It is evident that the absorption of the radioactive element is 


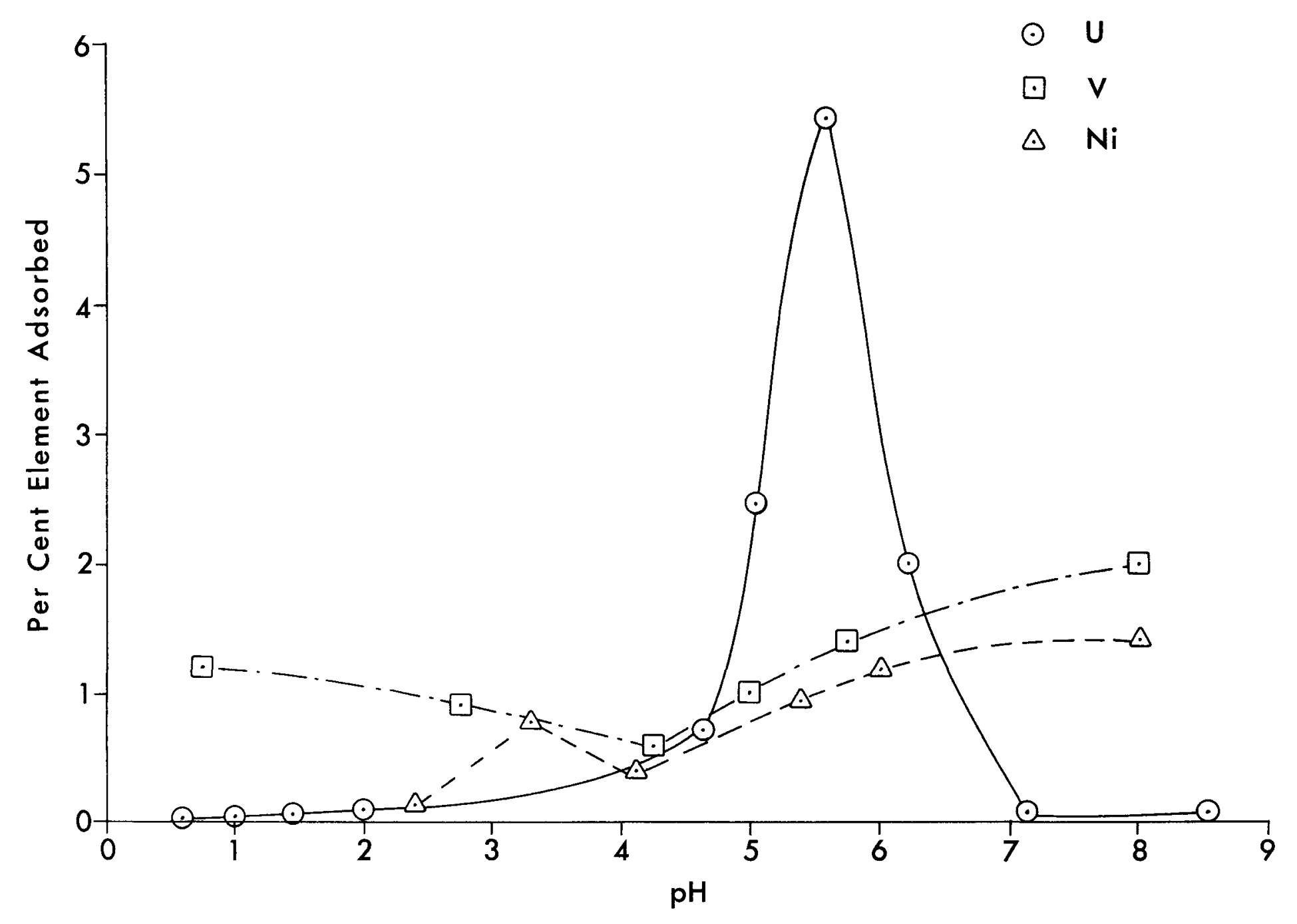

$\mathrm{pH}$ ISOTHERMS FOR URANIUM, VANADIUM AND NICKEL

Figure 1 
favored in the narrow $5-6.5 \mathrm{pH}$ range whereas absorption of vanadium and nickel increases gradually from pH 4 to 8 .

The effect of temperature (within the $20^{\circ}$ to $40^{\circ} \mathrm{C}$ range studied) was found to be negligible. On the other hand, lack of oxygen (produced by evacuation or the use of carbon dioxide or nitrogen gas) almost doubled the amount of uranium but did not change the amount of $\mathrm{Ca}$ and $\mathrm{Ni}$ that could be adsorbed. Although the exact mechanism is not understood, it is apparent that the presence of reducing conditions favors absorption of more uranium.

Evidence that sorption is the most important mechanism involved in the uptake of uranium in part of the system under study is provided by measurement of the absorption of various ions ( $\mathrm{Na}, \mathrm{Ca}, \mathrm{Mo}, \mathrm{Ni}$, $\mathrm{Co}$ and $\mathrm{U}$ ) on humic acid extracted from the lignite:

If the humic acid is saturated with either sodium or calcium ions before the reaction with uranium, there is a displacement of the cation by uranium. Even when the reaction solution was carefully bufféred at the optimum $\mathrm{pH}$ for maximum adsorption of uranium the $\mathrm{pH}$ of the solution increased as the amount of uranium adsorbed increased. Analyses of the equilibrium soiutions also showed that the amount of sodium and calcium displaced from the sorbent increased. On the other hand, if the humic acid was purified after extraction by elution with dilute hydrochloric acid in a chromatographic column, until analysis of the eluate showed that no sodium or calcium was present, and was then eluted with distilled water until a negative test for chloride was obtained, the $\mathrm{pH}$ of the buffered reaction solution decreased as more uranium was adsorbed.

Samples of the lignite and humic acid that were first reacted with 
solutions containing $\mathrm{Mo}, \mathrm{Ni}$ and $\mathrm{Co}$, washed and dried, and then reacted with a solution containing only uranium, showed a decrease by about one-half in the amount of uranium sorbed. If, however, the uranium was added to the solutions containing molybdenum, nickel, and cobalt and reacted; the decrease in uranium sorption was negligible, whereas the sorption of the other ions decreased noticeably.

Area IV - Petrography of Western Lignites and Related Materials

Petrographic studies were instituted in 1952 in the hope of determining the extent to which the composition of a given lignite seam influenced the distribution of radioactive materials within the seam, The initial studies showed that the seams are stratified rock bodies in which each of the component strata are composed of a coal type that differs from the coal types forming juxtaposed strata. Each coal type consists of a distinctive assemblage of maceral and mineral materials. The nature of the constituent materials in each assemblage suggests that each coal type represents a different environment of deposition. One would expect these environments to vary widely in shape and areal extent. Also, the geochemical conditions attending sedimentation and the nature of plant source materials can be expected to be different in dissimilar environments. In view of this it seemed logical to conclude that both primary and secondary concentrations of uranium in coal seams might be correlated with the coal types present and therefore with the paleogeography and paleoecology of the region involved. It appeared to follow from the above that paleogeographic knowledge would implement exploration for uranium sources.

Although the uraniferous lignite seams were seen to be composed of differing coal types, one superposed upon another, it was impossible to 
attach ecological significance to the various coal types because of lack of knowledge in this realm. Accordingly, one of the first products of the petrographic research was establishment of the need to embark on research in modern coal-forming environments. If the relationships between environmental conditions and the type of peat could be established, then peat types could be correlated with the coal types found in the lignite seams and paleogeographies might then be reconstructed. This research was undertaken and the results are presented in another section of this report.

As a second product of the initial petrographic studies, the investigators were alerted to the potential of palynological investigations with respect to resolving stratigraphic problems, estimating uranium reserves and reconstructing paleoecological conditions (NYO-3364). This came as the result of observing abundant well-preserved pollen and spores in the samples being studied petrographically. To exploit this potential, an additional area of research was included in the total program and its products are described in the next section of the current report.

During the course of the petrographic investigations, 333 samples were analyzed. These represent a total of 10 seams from South and North Dakota. Results derived from these investigations have shown that the lignitic material composing the seams has been derived, for the most part, from angiospermous as opposed to coniferous plants (NYO-3364). The organic materials forming the seams are optically recognizable as macerals of the vitrinite, fusinite, micrinite, exinite and resinite maceral series. Macerals that are not properly classed with any of these recognized metamorphic series also were encountered and described. This descriptive information is proving to be of value in connection with an international effort 
$$
\text { . }
$$ 
in a rapid manner. Large quantities of chitinous fungal remains at particular seam levels reflect periods during which the coal source materials were subjected to abnormal sub-aerial decay. Such levels are usually deficient in pollen and spore materials and those present are badly corroded, indicating an increase in the importance of oxidation. The relative abundance of tracheid fragments in the maceration residues is positively correlated with the degree to which the Taxodiaceae-Cuppressaceae pollen assemblage is represented. This technique appears to complement both petrographic and palynological methods and constitues an advance in the technology of the compositional analysis of lignites.

Area V - Palynology of Dakota Lignites

The polien and spore contents of 741 samples have been determined. More than 200 species belonging to 75 different genera have been identified and the majority of these have been fully described following normal taxonomic procedures. Ninety-six of the species and 19 genera are thought to be new. Palynological profiles have been prepared for eleven uraniferous lignite seams and these data have been compared with appropriate chemical and petrographic data. The most significant result is the recognition of a welldefined positive correlation between the presence of the "MyricaceaeBetulaceae" pollen assemblage and uxanium concentration. This pollen assemblage is characteristic of one of the attrital lithotypes found in several of the lignite seams and must therefore reflect a particular sedimentary environment. In addition, the pollen profiles are different fox each of the WiL1iston Basin seams studied, 1ndicating that it is often possible to Identify seams by palynological techniques. This has direct application. in connection with understanding the geology of this and similar areas and 
accurate seam identifications are essential to achieving reliable estimates of uranium reserves.

The palynological data have clarified to a considerable degree the manner in which spores and pollen should be used in effecting seam correlations, identifying coal lithotypes and reconstructing paleogeographic settings. For the horizons studied, fern spores appear to be useful only in recognizing localized environmental conditions. Their variability from place to place in the same seam renders them useless in distinguishing regionally extensive rock bodies, pollen assemblages or paleogeographic features. In contrast, a detailed description of variations in angiospermous and gymnospermous pollen occurrences through the thickness of a seam, plus a record of the frequency of fungal spore occurrences appears to be an effective means of establishing a seam's identity. Simultaneously and by virtue of the correlations established between palynological and petrographic data, such descriptions have proved useful in providing a gross assessment of the petrographic composition of a given seam and the regional extent of its constituent strata.

Palynological studies of Paleocene lignite seams in the Slim Buttes area of Harding County, South Dakota have shown that the pollen flora contains a mixture of temperate and subtropical species. A detailed investigation of three cores, each of which included the same seams, has demonstrated that closely spaced coal beds and even benches of a single seam can often be identified by palynological means. For example, the lower bench of the Olesrud seam was reabily distinguished by the consistently large quantities of a particular Sphagnalean spore that it contains over an area of many square miles. 
A detailed study of the Mendenhall seams in the Slim Buttes area has revealed a flora consisting of 45 genera and 68 species; 4 genera and 23 species are described as new. The most abundant species are: Taxodieaepollenites hiatus, followed by Betulaepollenites claripites, Ostryoipollenites krempi, Triporopollenites farenosus, Salicoidites tritus, Tricolpites confertus, Alsophilidites kerguelensis, Concavisporites rugulatus, Perotriletes dakotaensis, Polypodiisporites favus and Monolites discordatus. This assemblage is similar to that of the Eocene Green River Oil Shales and the eariy Tertiary brown coals of Germany.

Studies of the vertical distribution of the spores show that a successive series of vegetational units occupied the area during the deposition of the Paleocene sediments. By noting the stages of the plant succession, two zones and four subzones were established in the first lignite seam, second lignite seam and second clay seam. Zone I, characterized by a dominance of Taxodieaepollenites hiatus, was divided into four subzones containing the following miospore assemblages:

Subzone Ia: Taxodieaepollenites hiatus, associated with Salicoidites tritus, Salicoidites amplus, Tricolpites reticulatus, and Tricolpites metauraensis.

Subzone Ib: Taxodieaepollenites hiatus, associated with Myricipites dubius, Salicoidites amplus, Salicoidites tritus, and Tricolpites confertus。

Subzone IC: Taxodieaepollenites hiatus associated with Larixpollenites magnus, Hymenophyllumsporites del toida, Cyathidites diaphana, and Monolites discordatus. 
Subzone Id: Taxodieaepollenites hiatus associated with Triporopollenites falcatus, Cupaniedites major, Salicoidites amplus, Caprifolitpites viridi-flumins, Larixpollenites magnus, Cyathidites diaphana, Alsophilidites kergulensis, Concavisporites rugulatus, Perotriletes dakotaensis, Polypodiisporites favus, and Monolites discordatus.

Zone II: Betulaepollenites claripites, Ostryoipollenites krempi, Triporopollenites farenosus, and Salicoidites discoloripites.

The differentiation of these zones and subzones was made possible by the sampling technique, i.e. columns sampled at one and two inch intervals, and the quantitative analysis at the species level. This approach permitted the development of data that emphasized the importance of each species as to associations, occurrence, and maximum and minimum frequencies at specific levels within the seams. This resulted in the recognition that each seam possessed a particular uniqueness with respect to pollen content.

The studies of the Iateral distribution of pollen and spores show that, although some variations do occur, the configurations of the spectra representing each species are similar. The principal exceptions occur among the trilete and monolete spores. These results indicate that a single column, sampled at one inch intervals and from an outcrop of reasonable extent, may be adequate to describe the composition of the flora. Also, because of the wide fluctuations of their spectra, the trilete and monolete miospores are of limited value in the correlations of Paleocene sediments.

A separate palynological study involved the Cave Hills, Crow Butte and 
Twin Butte areas of northwestern South Dakota. Three sections of Upper Cretaceous and Lower Tertiary strata were measured, described, and sampled in approximately two weeks during the summer of 1956 and in two weeks during the summer of 1958. The three sections, in their combined thickness, represent 877.1 feet of strata. A total of 106 samples were collected, 59 of which contained sporomorphae whereas the remainder proved to be barren. The sporomorphae are found to be assignable to 106 species and 3 subspecies represented by 49 genera; 73 species, one subspecies and six genera are thought to be new.

Both the Crow Butte and the Cave Hills sections are divided into three zones which are based on "characteristic" species. The species that are thought to delimit the zones and other species that are thought to be typical for each of the sections, independent of depositional environment, have been described and discussed in some detail. Also described and discussed are the 13 species found to occur in a nondistinctive manner in both the Cave Hills and Crow Butte sections.

Evidence is presented that there is no major floral break within the Cave $H_{i} I 1 s$ section, but a major floral break exists between the Cave Hills and Crow Butte sections. The Cave Hills and Crow Butte sections have on $1 y$ 12\% of the total described species in common. It is suggested that this difference is not the result of depositional environment but is a real stratigraphic difference. In addition, the sporomorphae present throughout the Cave Hills section have a decidedly modern aspect as contrasted to those present in the Crow Butte section, suggesting a major difference in composition in the floras as represented by the sporomorphae. The Twin Butte section, which is thought by some to contain the 
Cretaceous-Tertiary boundary, has a sporomorph assemblage that contains many of the diagnostic species of Zone II of the Lower Tertiary Cave Hills section. No species that are characteristics of the Upper Cretaceous Crow Butte section were found in the Twin Butte section.

The data presented suggest the following conclusions:

1. The Cave Hills section, in its entirety, is lower-most Tertiary in age, inasmuch as some of the species that occur throughout this section have been reported from the lower-most Tertiary of Europe. Although three zones are established within this section, no major floral break is suggested and no floral break whatsoever is found at the color contact commonly regarded as the Cretaceous-Tertiary boundary.

2. The Crow Butte section is uppermost Cretaceous. This section is divisible into three zones on the basis of the sporomorphae present. The Crow Butte sporomorph assemblage is markedly different from any of the European and Australian Upper Cretaceous assemblages and most closely resembles the assemblage described by Rouse from western Canada which is slightly older in age.

3. Tre Twin Butte section does not contain the Cretaceous-Tertiary boundary, but is actually correlative with Zone II of the Cave Hills section.

4. The precise stratigraphic position of the major floral break between the Cave Hills and Crow Butte sections was not found in any of the three sections measured and sampled.

The location of the section where the major floral break takes place is of prime importance for future investigation. It would be interesting to discover whether or not this change from a more or less archaic floral assemblage to one relatively modern in appearance takes place at a sharp 
boundary or is gradual in nature. It would also be interesting for some future worker to relate the sporomorphae of the Cave Hills section to their extant counterpart and in this way interpret the environment of the area in early Tertiary time.

In connection with the taxonomic facets of the palynological studies, it became necessary to compile a reference atlas of the descriptions on which the numerous species of fossil spores and pollen are based. The value of this compendium was recognized by visiting scientists and we were urged to compile and publish a "Catalog of Fossil Spores and Pollen". This effort was initiated in 1957 and 22 volumes have been published to date plus two volumes of "Translations" of Russian descriptions and a "Cumulative Index". In addition to providing a sound basis for the taxonomic treatment of the spores and pollen encountered in the uraniferous lignites of the West, the Catalog provided a means of establishing equivalency with strata in other parts of the world. Funds required for initial development of the "Catalog project" were derived from several sources, each in proportion to the estimated vaiue of the compendium to the particular research involved. Its gradual evolution to the status of a standard reference work now permits it to continue on a self-supporting basis.

Area VI - Modern Phyto-organic Sediments and Sedimentary Environments The investigation of modern phyto-organic sediments was initiated on a modest scale during the last half of the contract period in the hope of providing a sound basis for interpreting the geochemical history of uraniferous carbonaceous sediments and through this, achieving an adequate description of the factors influencing uranium concentration.

Field study of extant swamp environments in the Atlantic and Gulf 
Coastal Plain areas of southeastern United States resulted in the recognition of 16 distinct major environments in which phyto-organic sediments are now accumulating. This is only a portion of the total number of environments important in forming coal and includes:

The Fringe Marine Environmerts:

1. Red Mangrove Environments (Tropical to Sub-tropical)

2. Black Mangrove Environments (Tropical to Sub-tropical)

3. Salt Marshes (Warm Temperate - Temperate)

4. Open Water Environments

The Brackish Environments

5. Mixed Mangrove Environments

6. Brackish Everglades Environments

7. Salt Marsh Complexes

8. Open Water Environments

The Fresh Water Environments

9. Fresh Water Everglades

10. Cypress Swamps

11. Gumwood Swamps

12. Titi Swamps

13. Hardwood Forest Complexes

14. Shrub Complexes

15. Rush - Grass - Cattail Complexes

16. Open Water Environments

Southwestern Florida was chosen as the area in which to initiate intensive studies because of (1) the relative simplicity of the plant communities in the coal-forming environments, (2) the well-defined 


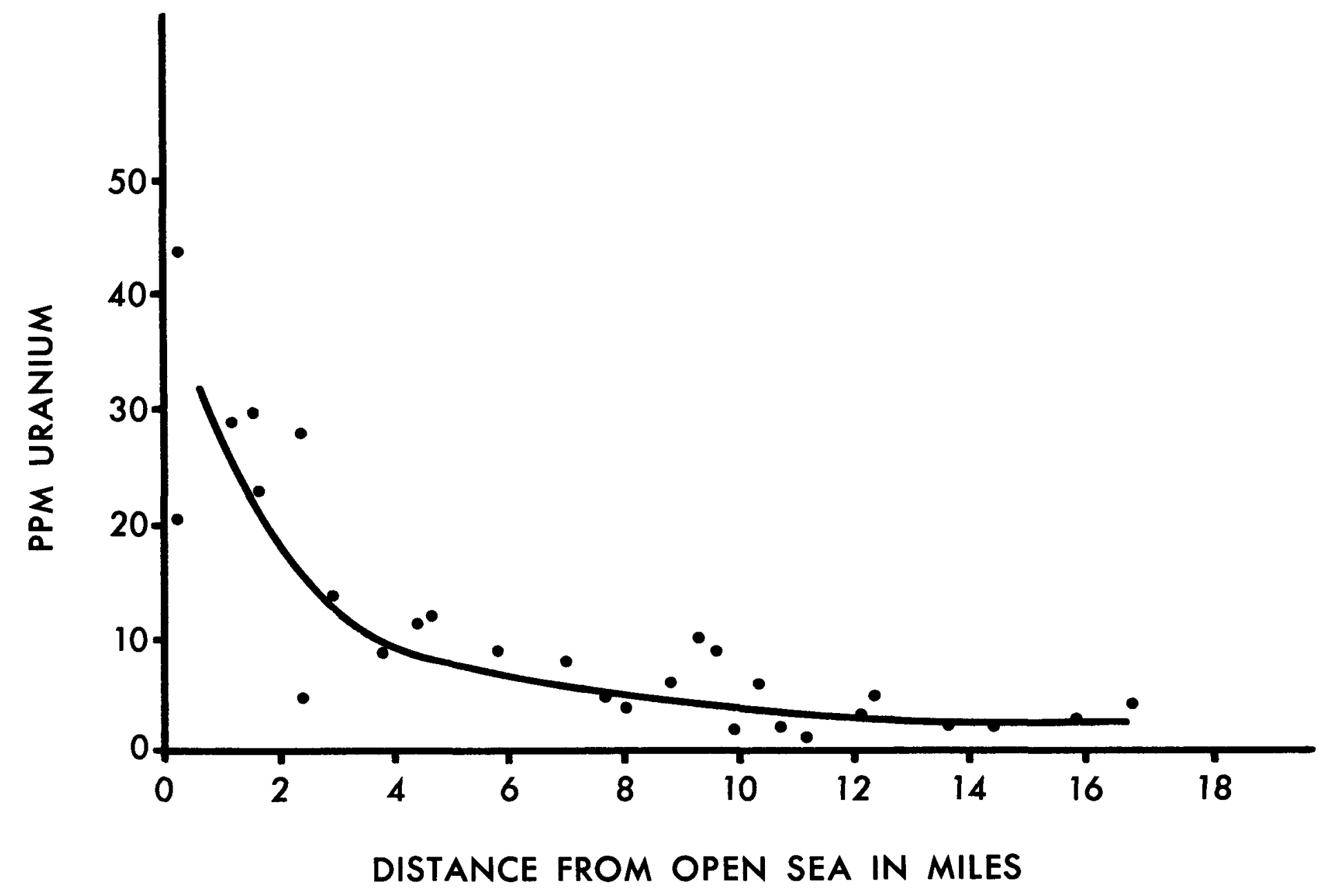

DISTRIBUTION OF URANIUM ALONG THE SHARK RIVER

Figure 2 


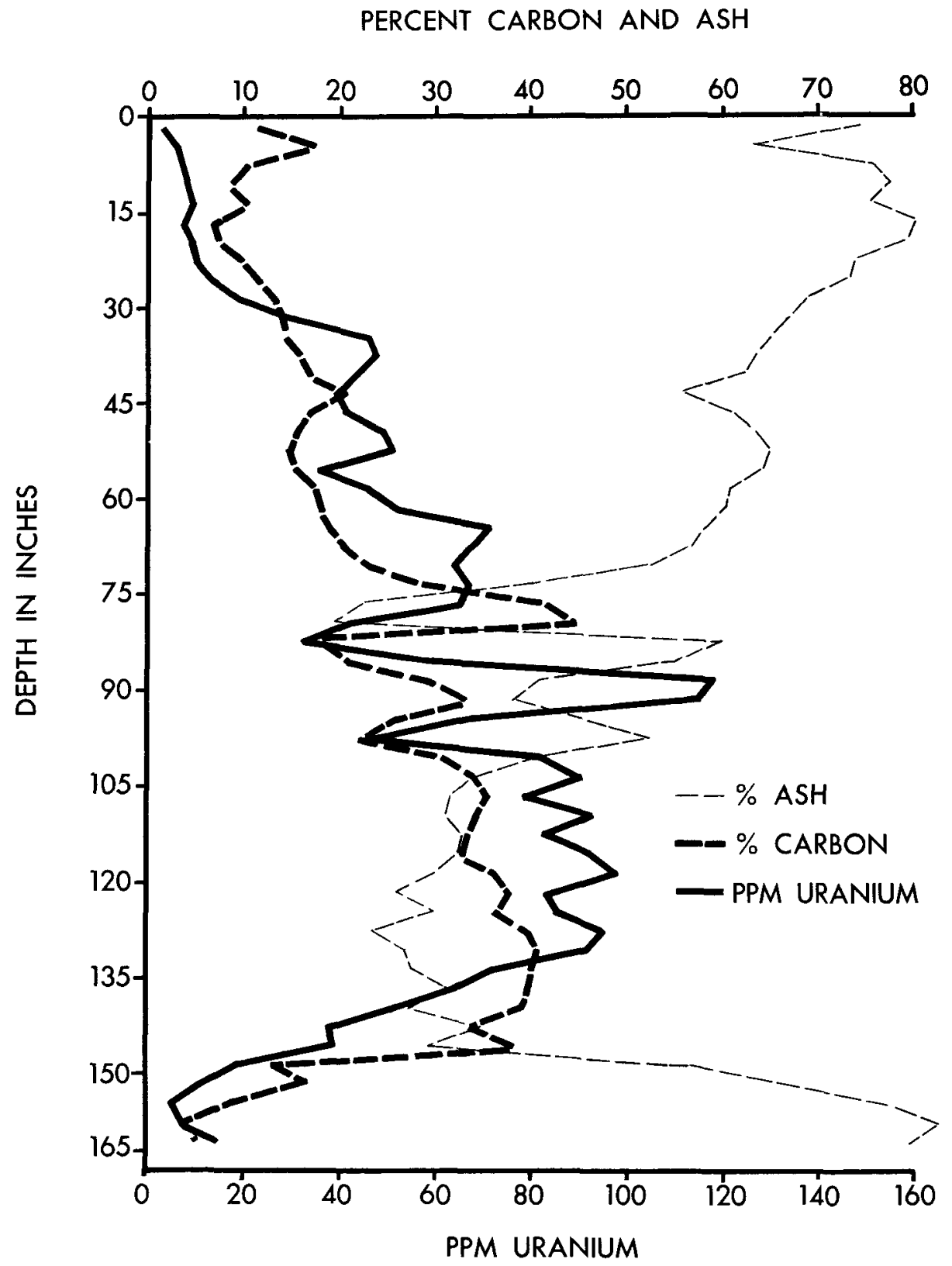

VARIATION IN CARBON AND URANIUM CONTENT AT SITE 59-TI Figure 3 
boundaries between adjacent environments and (3) the availability of extensive marine, brackish and fresh water environments within a single area and all producing coal source materials.

Data thus far obtained have shown unexpectedly high concentrations of uranium in both surface and sub-surface peats. These facts coupled with results from laboratory experiments designed to evaluate the uranium adsorptive capacity of various peats, led to formulation and submission of a research proposal to the Commission suggesting the more detailed study of peat deposits as potential waste reservoirs.

The investigations in southwestern Florida have been focused upon a series of marine, brackish and fresh water environments. The uranium content in the sediment commonly reflects the proximity of the environment to the open marine waters of the Gulf (Figure 2). This, of course, suggests the marine waters as the source of the uranium in these sediments. Also of interest is the consistent inverse relationship between the ash yield (hence mineral content) and the uranium content in these peats. In contrast, the carbon content of the peat is positively correlated with the uranium concentration. This applies to surface samples as well as to buried peats. Such relationships are shown in Figure 3 which presents data from a typical core taken at the shoreline.

Data obtained on the sulfur content in the peat also are of interest. Sulfur has often been thought of as a material that is emplaced in coal seams subsequent to the burial and consolidation of the peat. In other words, much of the sulfur in the lignites of the Williston Basin has been thought of as being of secondary origin. In view of this, it is of interest to find that certain layers of the peats contain in excess of 4 percent of 
this element. Sulfur profiles prepared for two of the cores are quite equivalent to the vertical distribution patterns encountered in ancient sediments. This would appear to raise a question as to the extent to which sulfur concentrations in coals are truly secondary in the sense of having been derived from materials outside of the consolidated seam.

Aralyses obtained from samples representing a variety of environments are equally interesting. Marked differences in the concentration of uranium, calcium, magnesium, iron, sulfur, silica and other elements appear to be evident between petrographicaliy distinct peat types. After these data are substantiated and supplemented it should be possible to relate each type of organic sediment to its parent environment and to its geologic equivalent in lignite and coal seams of higher rank. Such information together with a knowledge of the physical and chemical properties of the various lithotypes should be useful in achieving the desired efficiency in exploiting carbonaceous uranium ores.

\section{Summary of Other Contributions of the Program}

\section{A. Publications and Reports}

Bates, T.F., W. Spackman, G. Brunton, E.F. Koppe and C.L. Trotter, 1952. The mineralogy, petrography and paleobotany of uranium-bearing shales and lignites. Quart. Prog. Rept. U.S.A.E.C. (Scope B) NYO-3360:1-20. 1952 . The mineralogy, petrography and paleobotany of uranium-bearing shales and lignites. Quart. Prog. Rept. U.S.A.E.C. (Scope B) NYO-3362:1-23.

Bates, T.F., W. Spackman, G. Brunton, E.F. Koppe, C.L. Trotter and E. Erickson, 1953. An investigation of the mineralogy, petrography and paleobotany of uranium-bearing shales and lignites. Ann. Prog. Rept. U.S.A.E.C. (Scope B) NYO-3364:1-53.

Bates, T.F., H.D. Wright and S.J. Skipper, 1958. Geological studies of uraniferous minerals and rocks by fission fragment radiography. Proc. XX Int. Geol. Cong. 
Koppe, E.F., E.Erickson, C.L. Trotter, W. Spackman and T.F. Bates, 1953. An investigation of the mineralogy, petrography and paleobotany of uranium-bearing shales and lignites. Quart. Prog. Rept. U.S.A.E.C. (Scope B) NYO-3366:1-22.

, 1953.

An investigation of the mineralogy, petrography and paleobotany of uranium-bearing shales and lignites. Quart. Prog. Rept. U.S.A.E.C. (Scope B) NYO-6057:1-27.

Koppe, E.F。E.S. Erickson, C.L. Trotter, R.S. Good, W. Spackman and T.F. Bates, 1953. An investigation of the mineralogy, petrography and paleobotany of uranium-bearing shales and lignites. Quart. Prog. Rept. U.S.A.E.C. (Scope B) NYO-6059:1-19.

, 1954. An investigation of the mineralogy, petrography and paleobotany of uranium-bearing shales and lignites. Third Ann. Rept. U.S.A.E.C. (Scope B) NYO-6061:1-98.

, 1954. An investigation of the mineralogy, petrography and paleobotany of uranium-bearing shales and lignites. Quart. Prog. Rept.U.S.A。E。C. (Scope B) NYO-6063:1-12.

, 1954. An investigation of the mineralogy, petrography and paleobotany of uranium-bearing shales and lignites. Quart. Prog. Rept. U.S.A.E.C. (Scope B) NYO-6065:1-16.

Koppe, E.F., E.S. Erickson, C.L.Trotter, R.S. Good, A.R. Cameron, W. Spackman and T.F. Bates, 1955. An investigation of the mineralogy, petrography and paleobotany of uranium-bearing shales and lignites. Ann. Prog. Rept. U.S.A.E.C. (Scope B) NYO-6069:1-84.

Kremp, G.O.W. and E.S. Erickson, 1955. An investigation of the mineralogy, petrography and paleobotany of uranium-bearing shales and lignites. Quart.Prog. Rept.U.S.A.E.C. (Scope B) NYO-7421:1-18.

and W. Spackman, 1957-1965. Catalog of Fossil Spores and Pollen, Volumes 1 - 22, 4636 pages.*

, H.T. Ames and N.O. Frederiksen, 1959. The organ-species concept and the International Code of Botanical Nomenclature. Taxon, $8(3): 91-95$.

and N.O. Frederiksen, 1960. Recognition of lithotypes by palynological methods. Proc. Ist Int. Cong. for Coal Petrography Proc. \#3.

* See following pages for complete Catalog references. 
Kremp, G.O.W., and A.J. Kovar, 1960. The interpretation of Tertiary swamp types in brown coal. U.S.G.S. Prof. Paper 400-B:79-81.

, and J.E. Gerhard, 1961. Pollen and spores from the Lower Tertiary of North and South Dakota and some taxonomic problems concerning their designation. Proc. Third Conf. on the Origin and Constitution of Coal, Crystal Cliffs, Nova Scotia, pp. 257-269.

R.C. Neavel and J.S. Starbuck, 1961. Coal types: a function of swamp environment. Proc. Third Conf. on the Origin and Constitution of Coal, Crystal Cliffs, Nova Scotia, pp. 270-286.

O'Neil, R.L., 1958. Analytıcal procedures applicable to fine-grained sedimentary rocks. Tech. Rept.U.S.A.E.C. NYO-7906:1-34.

, 1959. Analytical procedures applicable to fine-grained sedimentary rocks. Jour. Sed. Pet. 29:267-280.

and C.P. Dolsen, 1960. Analyses of Florida peats. Tech. Rept.U.S.A.E.C. NYO-7950:1-11.

and N.H. Suhr, 1960. Determination of trace elements in Iignite hashes. Applied Spectroscopy 14:45-50.

Spackman, W., E.F. Koppe, R.S. Good, T,F. Bates, 1954. An investigation of the mineralogy, petrography and paleobotany of uranium-bearing shales and lignites. Quart. Prog. Rept. U.S.A.E.C. (Scope B) NYO- $6067: I-14$.

, 1958. The maceral concept and the study of modern environments as means of understanding the nature of coal. Trans. N.Y. Acad. Sci., Ser. II, $20(5): 411-423$.

. and C.P. Dolsen, 1961. The characteristics of modern organic sediments and their use in the identification, description and interpretation of carbonaceous rocks and rock sequences. Proc. CoastaI and Shallow Water Research Conf. Tallahassee, Florida, pp. i55-160。

and R.R. Thompson, 1964. A coal constituent classification designed to evolve as knowledge of coal composition evolves. 15th Int. Cong. de Strat. et Geol. du Carbonifere, Compte Rendu, pp. 239254.

D.W. Scholl and W.F. Taft, 1964. Environments of coal formation in southern Florida. Guidebook G.S.A. Ann. Meetings, Miami Beach, Fla., pp. 1-65.

Stanley, E.A. and G.O.W. Kremp, 1959. Some observations on the geniculus in the pollen of Quercus prinoides. Micropal. 5(3):351-354. 
Tietjen, J.J., 1958. On the chemical constitution of a lignitic resin. Tech. Rept. U.S.A.E.C. NYO-7974:1-56.

White, E.W., 1958. Uranium mineralization in some North and South Dakota lignites. U.S.A.E.C. NYO-7448:1-79.

, H.A. McKinstry and T.F. Bates, 1958. Crystal chemistry studies by $x$-ray fiuorescence. Proc. 7 th Ann. Conf. Indus. Appl. of X-ray Analysis, pp. 230-245.

Kremp,G.W.O. and W. Spackman, Catalog of Fossil Spores and Pollen, The Pennsylvania State University, University Park, Pennsylvania

Volume I, Cretaceous and Tertiary Spores and Pollen, as compiled by G. Kremp, H.T. Ames and H. Grebe, 1957

Volume 2, Mesozolc and Tertiary Spores and Pollen, as compiled by G. Kremp, H.T. Ames and H. Grebe, 1958

Volume 3, Tertiary Spores and Pollen, as compiled by G. Kremp, H.T. Ames and H. Grebe, 1958

Volume 4, Cretaceous and Tertiary Spores and Pollen, as compiled by G. Kremp, H.T. Ames and A.J. Kovar, 1958

Volume 5, Carboniferous Spores, as compiled by G. Kremp and H.T. Ames, 1959

Volume 6, Pennsylvanian Spores, as compiled by G. Kremp and H.T. Ames, 1959.

Volume 7, Mississippian and Pennsylvanian Spores, as compiled by G. Kremp, H.T. Ames and A.J. Kovar, 1959

Voiume 8, Cretaceous Spores and Pollen, as compiled by G. Kremp, H.T. Ames and A.J. Kovar, 1959

Volume 9, Triassic and Jurassic Spores and Pollen, as compiled by G. Kremp, H.T. Ames and A.J. Kovar, 1960

Volume 10, Jurassic and Cretaceous Spores and Pollen, as compiled by G. Kremp, H.T. Ames and A.J. Kovar, 1960

Volume 11, Devonian Spores, as compiled by G. Kremp, H.T. Ames and A.J. Kovar, 1960

Volume 12, Devonian Spores, as compiled by G. Kremp, H.T. Ames and A.J. Kovar, 1960

Volume 13, Carboniferous and Permian Spores, as complled by G. Kremp and H.T. Ames, 1961

Volume 14, Mesozolc and Tertiary Spores and Pollen, as compiled by G. Kremp and H.T. Ames, 1961

Volume 15, Tertiary and Cretaceous Spores and Pollen, as compiled by G. Kremp and H.T. Ames, 1962 
Volume 16, Mesozoic and Lower Tertiary Spores and Pollen, as compiled by G. Kremp and H.T. Ames, 1962

Volume 17, Paleozolc Spores, as compiled by G. Kremp and H.T. Ames, 1962

Volume 18, Late Paleozoic Spores, as compiled by G. Kremp and H.T. Ames, 1962

Volume 19, Tertiary Spores and Pollen, as compiled by H.T. Ames, G. Kremp and W. Riegel, 1963

Volume 20, Late Paleozoic Spores and Pollen, as compiled by H.T. Ames, G. Kremp and W.L. Riegel, 1963

Volume 21, Early and Late Tertiary Spores and Pollen, as compiled by H.T. Ames and G. Kremp, 1964

Volume 22, Middle and Upper Paleozoic Spores and Pollen, as compiled by G. Kremp and H.T. Ames, 1964

B. Theses

Gerhard, J.E., 1958. Paleocene microspores from the Slim Buttes Area, South Dakota。M.S. Thesis, The Pennsylvania State University.

Neavel, R.C., 1957. Some aspects of the petrography of western lignites. M.S. Thesis, The Pennsylvania State University.

Savanick, G.A., 1961. An investigation of jarosite found in some radioactive lignites. M.S. Thesis, The Pennsylvania State University

Stanley, E.A., 1960. Upper Cretaceous and Lower Tertiary sporomorphae from northwestern South Dakota. Ph.D. Thesis, The Pennsylvania State University.

Tietjen, J.J., 1958. On the chemical constitution of a lignitic resin. M.S. Thesis, The Pennsylvania State University.

Trotter, C.L., 1963. Palyno-botanical and stratigraphic studies of three lignite drill cores (Paleocene) from Harding County, South Dakota. Ph.D. Thesis, The Pennsylvania State University

White, E.W., 1958. Uranium mineralization in some Noxth and South Dakota IIgnites.M.S. Thesis, The Pennsylvania State University.

C. Papers Presented at Scientific Meetings

Bates, T.F., H.D. Wright and S.J. Skipper, 1957. Geological studies of uraniferous minerals and rocks by fission fragment radiography, $\mathrm{XX}$ Int. Geol. Cong., Mexico City. 
Dolsen, C.P., 1958. The significance of modern environments in determining 1ithotypes. Second Conf. of Eastern American Anthracologists, May 26-27, University Park, Pa.

Koppe, E.F. and W. Spackman, 1956. Preliminary observations on banding in peat. G.S.A. Ann. Meetings, Oct. 31, Nov. 1-2, Minneapolis, Minn.

Koppe, E.F。 and W. Spackman, 1959. The transition from peat to lignite. Div. of Gas and Fuel Chem., Amer. Chem. Soc., April 5-10, Boston, Mass.

Kremp, G.O.W., and J.E. Gerhard, 1956. Pollen and spores from the Lower Tertiary of North and South Dakota and some taxonomic problems concerning their designation. III Conf. on the Origin and Constitution of Coal, June 20-22, Crystal Cliffs, Nova Scotia.

Kremp, G.O.W., R.C. Neavel and J.S. Starbuck, 1956. Coal types: a function of swamp environment. III Conf. on the origin and Constitution of Coal, June 20-22, Crystal Cliffs, Nova Scotia.

Kremp, G.O.W., H.T. Ames and N.O. Frederiksen, 1958. The organ-species concept and the International Coke of Botanical Nomenclature. 5th National Pollen Conf. (A.I.B.S. meeting) August 24-28, Bloomington, Indiana

Kremp, G.O.W. and N.O. Frederiksen, 1958. Recognition of coal lithotypes by palynological methods. First Int. Cong. on Coal Petrology, Sept. 10-13, Heerlen, Netherlands

Kremp, G.O.W., 1959. Can the expanding palynology escape taxonomic chaos? Int. Bot. Cong., August, Montreal, Canada.

Kremp, G.O.W., A.J. Kovar and W.L. Riegel, 1959. Pollen and spore content of modern organic sediments from Florida compared to the microfloral assemblages characterizing lithotypes of Tertiary coal seams from Germany and South Dakota, G.S.A. Ann. Meeting, November 2-4, Pittsburgh, $\mathrm{Pa}$.

Neave1, R.C., 1958. Problems in the description of lignitic coals, 2nd Conf. of Eastern Amer. Anthracologists, May 26-27, University Park, Pa.

Spackman, W., W.F. Berry and E.F.Koppe, 1954. Various aspects of the problem of petrographic nomenclature. Conf. on Coal Microscopy, U.S. Bur. Mines, November 8-9, Pittsburgh, Pa.

Spackman, W., 1958. The maceral concept and the study of mod ern environments as means of understanding the nature of coal. N.Y. Acad. of Sci., Sect.on Geology and Mineralogy, February 3, New York City, N.Y. 
Spackman, W. and C.P. Dolsen, 1960. Uranium sulfur, iron and mineral concentrations in organic sediments from selected marine, brackish and fresh-water environments. G.S.A. Ann. Meetings, Oct. 31, Nov. 1-2, Denver, Colorado

Spackman, W., 1961. The development of descriptive terminology at The Pennsylvania State University. International Comm. on Coal Petrology, May 15-17, Krefeld, Germany

Spackman, W., 1961. The nature of coal and coal seams. Ruhr Coal Petrographical Research Assoc., May 18, Essen Germany

Spackman, W. and R.R. Thompson, 1963. A coal constituent classification designed to evolve as knowledge of coal composition evolves. 15th International Congerss on the Stratigraphy and Geology of the Carboniferous, General Session, September 9-12, Paris, France.

Spackman, W。, W。L. Riegel and C.P. Dolsen, 1964. Geological and biological interactions in the swamp-marsh complex of southern Florida. G.S.A. Ann. Meetings, Nove. 19-21, Miami Beach, Florida.

D. Undergraduate and Graduate Training and Support

Individuals Supported as Geology-Mineralogy Graduate Students

H.T. Ames

W.A. Anderson

L.G. Benedict

W.F. Berry

E.H. Bogardus

G.J.Brenner

G. Brunton

A.R. Cameron

F.L. Canning

P. Y. Chen

C.P. Dolsen

R.R. Dutcher

E. Erickson

J. Fawkes*

J.E。 Gerhard

R.S. Good

E.F. Koppe

J. Krall***

R. Lewis

S.P. Mansfield
H. Meyer

B.D. Middleton

R.G. Moses

R.C. Neavel

G. Newman*

A. Pronay

W. L. Riegel

P. Saha

G. Savanick

M.V. Sel ander*

J.J. Shigo

W. Shulhof

R.S. Sohon

E.A. Stanley

R.W. Stingelin

J.M. Strickler*

J。K. Thamm

J.J. Tietjen**

C.L. Trotter

E.W. White

* - Student in Department of Chemistry

** - Student in Department of Fuel Technology

*** - Student in Department of Mathematics 
Individuals Supported as Undergraduate Students
R.C. Antrim
D. Lipport
R. J. Bednar
M. Markow
J. Bluhm
D.w. McKinney
L.A. Brantly
G. Mills
C.E. Carrman
S. Monroe
C. Clark
R.J. Conklin
B.L. Moyer
W.L. Daly
J.R. Myers
N. Fahrer
T.J.K. Peters
H.R. Fell
R.V. Ranochak
D. Fink
W.E. Reitz
F.I. Geisel
H. L. Rudio
E.J. Grindall
J.B. Shaffer
R.A. Hartswick
B.L. Sreinivas
R. Hinckel
S. Stanonis
R.L. Hirt
J.O. Starbuck
J.R. Hixon
T.M. Stash
S.M. Irving
D. Strickler
G. Lesoine
R.A. Strickler
B. Lezer
Mason Walsh
J. Libertino
M. Waxham
S. Lindemuth
M. Wimmer
J. Lipko
$\mathrm{K}$. Young
T. Zalinski

B. Zodikoff

$\underline{\text { Individuals Supported in Post-Doctoral Research }}$

H. Grebe

G.O.W. Kremp

Analyst

R.L. O'Neil

others (Technical and Clerical Assistants)
M. Bailey
S. McIntyre
B. J. Des Marais
E. Martinec
J.P. Dolsen
J. Mather
P.S. Dutcher
R. Organ
A.A. Erickson
J. Sipes
B. Ghaner
S.J. Skipper
S. Irving
P.Q. Wall
D. Keiso
R. Williams
E. Kremp

E. Technique Derelopment

As in many challenging research programs, the difficulties encountered in correctly evaluating the mineralogy, paleobotany and palynology of the 
lignites required the continuous development and use of new techniques. Because of the nature of the lignitic material, the "standard" sample preparation procedures used on other types of rocks and minerals (such as thin sectioning, polishing, and grinding; sampling for the electron microscope, etc.) had to be modified and often completely revamped. Due to the large number of samples studied, analytical procedures were streamlined, often by the use of methods - such as x-ray fluorescence which were so new that project work aided in their development and applicability to the problems of others. For a portion of the program, considerable emphasis had to be placed on radiometric techniques, resulting in various contributions to the science (e.g. see Bates, Wright and Skipper, 1958). Finally, of equal importance to the problems of data gathering, were those of data evaluation and here - with the continual assistance of Dr. J.C. Griffiths - progress made on the project was concurrent with the latest developments in the use of such statistical techniques as multiple regression, discriminant functions, and factor analysis and with the ever-expanding use of computers, in processing the large amounts of data.

Throughout the entire effort, this program permitted and provided for not only the advancement of scientific methodology, but, perhaps more important, acquainted many students and research workers alike with a wide variety of challenging problems and the means of overcoming them. F. Development of the Mineral Constitution Laboratories

The Mineral Constitution Laboratories (MCL) of Penn State's College of Mineral Industries were formally established in 1951 to make expensive research tools and analysts accomplished in their use, available to staff 
and students of the College. Included in the laboratories at that time were two electron microscopes, an electron diffraction unit, five $x-r a y$ diffraction machines, an infrared absorption spectrograph and a spectrophotometer。

Because of the nature and needs of the research program described herein, project personnel not only made intensive and extensive use of alI MCL facilities but played important roles in the development and support of laboratory operations. Thus, for example, the very large chemical analytical program required with the lignite study was greatly expedited by the use of $x$-ray fluorescence techniques to replace more tedious wet chemical methods for the measurement of many of the elements. At the same time, the large amount of calibration, sample preparation, and tectnique development work done by project personnel in order to make proper use of the new instrumental tools, did much to make $x$-ray fluorescence more useful to a wide variety of other uses of the laboratories. Similarly, project development of radiometric and fluormetric techniques for uranium determination, special analytical procedures using both spectroscopy and wet chemical analysis (see references by $0^{\prime N e i 1)}$ and the use of $x$-ray fluorescence for crystal chemical studies of valence and coordination states (White, McKinstry and Bates, 1958) are further fxamples of the numerous project activities which provided scientific support for the Iaboratory program.

The Mineral Constitution Laboratories have continued to grow in size, importance, and usefulness to an ever-widening group of users from the entire University and neighboring research laboratories. Financial and scientific support from this program at a critical developmental 
stage did much to make the operation a success.

G. Development of the Organic Sediments Laboratories

Research in coal petrology at The Pennsylvania State University

was reactivated in 1951 in response to industry's need for information

on the significance of coal composition with respect to metallurgical

coke production. With the aid of industrial grants, a research program

and a graduate instructional program was developed. The project sponsored

by the Commission facilitated extension of these programs into the

important and clearly related areas of lignite research and the investiga-

tion of modern organic sediments. Grants from other sources permitted

further development of the program to include anthracites and coals from

various latitudes and geologic settings. Out of this evolved the Organic

Sediments Laboratories of the College of Mineral Industries. The program

of the Laboratories is now broad in scope and includes undergraduate

instruction, graduate instruction and research in (1) paleobotany,

(2) palynology, (3) coal petrology and (4) modern organic sediments.

As a service to the science of palynology, the Laboratories compile and

publish the Catalog of Fossil Spores and Pollen. The Commission's

project played an important role in the development of this research

and instructional unit.

\section{References}

Bates, T.F., H.G. Wright, and S.J. Skipper, 1958. Geological studies of uraniferous minerals and rocks by fission fragment radiography. $\mathrm{XX}$ International Geol. Cong. Proc.

NYO-3364: Bates, T.F., W. Spackman, G. Brunton, E.F. Koppe, C.L. Trotter and E. Erickson, 1963. An investigation of the mineralogy, petrography and paleobotany of uranium-bearing shales and lignites. Ann. Prog. Rept. U.S.A.E.C. (Scope B), 1953. 
NYO-6061: Koppe, E.F., E. Exickson, C.L. Trotter, R.S. Good, W. Spackman and T.F.Bates, 1954. An investigation of the mineralogy, petrography and paleobotany of uranium-bearing shales and lignites. Third. Ann. Rept.U.S.A.E.C. (Scope B)

NYO-6069: Koppe, E.F., E.S. Erickson, C.L. Trotter, R.S. Good, A.R. Cameron, W. Spackman and T.F. Bates, 1955. An investigation of the mineralogy, petrography and paleobotany of uranium-bearing shales and lignites. Ann. Prog. Rept. U.S.A.E.C. (Scope B)

NYO-7949: Bates, T.F. and R.L. O'Neil, 1960. Analyses of lignite samples. Tech. Rept。U.S.A.E.C.

NYO-7950: O'Neil, R.L. and C.P. Dolsen, 1960. Analyses of Florida peats. Terh. Rept.U.S.A.E.C.

Savanick, G.A., 1961. An investigation of jarosite found in some radioactive Iignites (M.S. thesis, Penn.State Univ.)

Stern, T.W. and L.R. Stieff, 1956. Radium-uranium equilibrium and radiumuranium ages of some Colorado Plateau secondary minerals. U.S.A.E.C. Trese Eiements Invest. Rept. 482.

Tietjen, J.J., 1958. On the chemical constitution of a lignitic resin. (M.S. thesis, Penn. State Univ and NYO-7947)。

White, E。W., 1958. Uranium mineralization in some North and South Dakota lignites (M.S. thesis, The Penn. State Univ. and NYO-7948).

White, E。W., H.A. McKinstry and T.F. Bates, 1958. Crystal chemistry studies by $x$-ray fluorescence. Proc. 7 th Ann. Conf. Industrial Application of X-ray Analysis, pp. 239-245. 